\title{
Market Reaction to The Announcement of General Election Result of The President and Vice President of Indonesia in 2019 (Study on LQ 45 Stock Index on The Indonesia Stock Exchange)
}

\author{
Gede Pujaastawan* I Gusti Bagus Wiksuana \\ Faculty of Economics and Business, Udayana University, Bali, Indonesia
}

\begin{abstract}
This study aims to determine the impact of political issues on market reaction when announcing the results of the 2019 Indonesian president and vice president election. The population in this study are all companies listed on the LQ45 Stock Index on the Indonesia Stock Exchange from February 2019 to July 2019. Sample taken by using the census method of 45 companies. The type of data used is quantitative and qualitative data obtained from secondary sources collected by the nonparticipant observation method. To test the information content, this study uses an event study approach. In this study there were two periods of events tested, namely the announcement of the results of the presidential and vice presidential elections in 2019 based on the quick count of the Survey Institute and the real count of the General Election Commission. To test the significance of abnormal returns the One Sample Test is used. The results of this study indicate that at the time of the announcement of the general election results based on the Survey Institute's quick count, there was a significant positive average abnormal return on the second day after the event date, while at the announcement of the general election results based on the General Election Commission's real count, there was no abnormal average significant return after the event date. The results concluded that the market must carefully search for information and be able to predict situations that are influenced by political issues to avoid risk.
\end{abstract}

Keywords: event study, abnormal return, market reaction, political issues

DOI: $10.7176 / \mathrm{EJBM} / 12-3-15$

Publication date: January $31^{\text {st }} 2020$

\section{Introduction}

The main role of the capital market is the allocation of share capital ownership (Fama, 1970). The capital market facilitates the flow of funds, and thus allows financing and investment through securities transactions. According to Wiksuana (2017: 1), investment can be interpreted as an activity of placing funds in one or more assets for a certain period in the hope of earning income and / or increasing the value of investment. Stocks are the type of securities that investors are most interested in. According to Wiagustini (2014: 237), shares are a sign of ownership or ownership of a person or entity in a company. Before trading stocks, investors will make an analysis first by gathering available information. Markets where prices always fully reflect available information are called efficient (Fama, 1970).

Testing market efficiency will be faced with uncertainty. To measure these conditions the event study method is used. According to Binder (1998), the event study method has become a standard method for measuring market reactions that are reflected in changes in stock prices due to an announcement of an event. One of the events that can affect the capital market in Indonesia so that the information content must be analyzed by investors is the general election. 2019 became one of the historic political years for Indonesia because for the first time a simultaneous general election system was held. Based on the results of the Survey Institute quick count, the pairs of candidates for President and Vice President Joko Widodo and Ma'ruf Amin outperformed their rival pairs of candidates Prabowo Subianto and Sandiaga Salahuddin Uno. However, Prabowo Subianto seemed to reject the quick count results by holding a declaration of victory.

Ahead of the announcement of the election results by the General Election Commission, supporters of Prabowo Subianto and Sandiaga Salahuddin Uno continued to claim allegations of fraud in the general election. The political situation became increasingly heated when supporters of Prabowo Subianto and Sandiaga Salahuddin Uno planned to mobilize the masses to reject the decision of the General Election Commission. The mobilization of mass power or people power will be carried out when the General Election Commission announces the results of the general election winner planned earlier on May 22, 2019. People power basically contains an invitation to the entire community to jointly take to the streets and voice rejection of the results of the General Election Commission.

Quoted from the Tribun Batam (2019), the General Election Commission explained that from the original schedule of 22 May 2019, the determination of the results of the recapitulation of the general election was advanced to 21 May 2019. The acceleration was carried out because the General Election Commission had completed all recapitulation of votes, both inside and outside country. The recapitulation results stated candidate pairs Joko Widodo and Ma'ruf Amin were superior by winning a total of 85,607,362 votes or 55.50 percent, and candidate 
pairs Prabowo Subianto and Sandiaga Salahuddin Uno won a total of 68,650,239 votes or 44.50 percent of the total votes legitimate (Komisi Pemilihan Umum, 2019).

As a result of the recapitulation results of the General Election Commission, supporters of candidate pair Prabowo Subianto and Sandiaga Salahuddin Uno staged a peaceful protest to reject the decision. But the peaceful protest turned violent. Quoted from the BBC (2019), riots began from peaceful protests in front of the Badan Pengawas Pemilu Building on May 21, 2019, but the atmosphere became heated when clashes between the masses and the police began. The Head of the Police Public Relations Division, Inspector General M. Iqbal, said that the number of victims killed in the riots on May 21, 2019 to May 22, 2019 reached 9 people (Kompas, 2019).

Political issues that occurred during the series of general elections made investors faced with a situation of uncertainty. The relationship between political issues and investor behavior in the capital market has attracted much attention in the financial economy literature (Osuala, et al., 2018). According to Kabiru, et al. (2015), capital market performance was significantly influenced by the political environment during the general election period. The information content of political issues can affect stock prices. Investors must carefully analyze the content of available information.

\section{Literature Review and Hypothesis}

Markets where prices always "fully reflect" available information are called efficient (Fama, 1970). Furthermore Fama (1970), classifying forms of market efficiency into three groups according to the availability of information better known as the Efficient Market Hypothesis, that is weak form, semi strong form and the strong form. Fama (1991) categorizes weak form market efficiency testing into a test for return predictability, semi strong form market efficiency testing becomes an event study, and strong form market efficiency testing becomes a test for private information. Event study is an analysis to observe the movement of stock prices around the announcement of certain events that are believed to have an impact on corporate finance and economic stability in general. According to Brown and Reilly (2009: 162), the purpose of the event study is to examine the level of abnormal returns around events that contain information. Abnormal return is the difference between actual return and expected return.

Basically, stock investments are full of risks. One risk that can affect investment is political risk. Political events, especially in Indonesia, are the elections for the President and Vice President of Indonesia in 2019. The market is expected to react quickly when receiving information available when announcing the results of the general election. Several previous studies that have become empirical evidence of the relationship of political issues to market reactions as measured by abnormal returns were conducted by Imelda and Anggraeni (2014), Savita and Ramesh (2015), Khan, et al. (2015), Koulakiotis, et al. (2016) and Osuala, et al. (2018). The results of these studies prove that political issues make investors able to obtain abnormal returns. Based on the empirical evidence, the research hypothesis is formulated as follows:

H1: There is a market reaction to the announcement of the results of the 2019 Indonesian President and Vice of President elections based on the Survey Institute's quick count.

H2: There is a market reaction to the announcement of the results of the 2019 Indonesian President and Vice President elections based on the real count of the General Election Commission.

\section{Research Method}

This study uses a quantitative approach in the form of descriptive testing the hypothesis regarding abnormal returns caused by the announcement of the results of the 2019 president and vice president elections of Indonesia based on the quick count of the Survey Institute and the real count of the General Election Commission. This research was conducted on companies listed on the LQ45 Stock Index from February 2019 to July 2019 using the event study method. The object in this study is the market reaction which is measured using the variable abnormal return. The type of data used is quantitative data, namely the company's stock price data listed on the LQ45 Stock Index on the Indonesia Stock Exchange from February 2019 to July 2019 and qualitative data, namely data in the form of a list of company names listed on the Stock Index LQ45 on the Indonesia Stock Exchange from February 2019 to July 2019. The data in this study are secondary data obtained by accessing the websites www.idx.co.id and www.finance.yahoo.com. The population and sample in this study are all companies listed on the LQ45 Stock Index from February 2019 to July 2019, as many as 45 companies. The sample in this study was taken using the census method. The data collection method in this study uses the nonparticipant observation method.

Data analysis method used in this research is event study. Event studies are used in analyzing market reactions to the announcement of the results of the 2019 presidential and vice presidential elections of Indonesia based on the Survey Institute's quick count and the General Election Commission's real count. This research was conducted for 21 exchange days for each event, with the event period starting from 10 days before to 10 days after the event date. Announcement of the results of the general election of the President and Vice President of Indonesia in 2019 based on the Survey Institute quick count set on April 18, 2019 and based on the General Election Commission's real count set on May 21, 2019. Thus, this research began on April 2, 2019 until May 6, 2019 and May 7, 2019 to 
June 7, 2019.

\section{Results and Discussion}

Hypothesis testing of the market reaction to the announcement of the results of the general election of the President and Vice President of Indonesia in 2019 was carried out in two periods, namely at the time of the announcement based on the Survey Institute quick count and the General Election Commission's real count by observing the movement of the average abnormal return. The movement of the average abnormal return signifies that the market reacts, while the insignificance of the average abnormal return indicates that the market does not react. If the market reaction occurs no later than $\mathrm{t} 2$ (two days after the event date), it means that the market reacts quickly, on the contrary if the market reaction arises after $\mathrm{t} 2$, then the market can be said to be slow to react.

Based on the results of the Survey Institute quick count, the pair Joko Widodo and Ma'ruf Amin outperformed the pair Prabowo Subianto and Sandiaga Salahuddin Uno. The results of the average abnormal return caused by the announcement of the general election results based on the Survey Institute quick count showed a significant positive only on $\mathrm{t} 2$ (the second day after the event date). These results prove the market quickly reacted after ensuring the victory of Joko Widodo and Ma'ruf Amin. This positive reaction indicates that the market is satisfied with the leadership of Joko Widodo, who previously served as President of Indonesia for the period 2014 to 2019 and has high hopes for the next leadership period.

The insignificance of the average abnormal return at $\mathrm{t} 0$ (event date) and $\mathrm{t}$ ( (one day after the event date) reflects that the market is still concerned about the uncertainty of political issues that occur. Even though the Survey Institute quick count results stated that Joko Widodo and Ma'ruf Amin's pair were superior, Prabowo Subianto and Sandiaga Salahuddin Uno pair still declared themselves winners in the general election. In addition, the issue of fraud was also circulating during the general election period which led to protests from supporters of the couple Prabowo Subianto and Sandiaga Salahuddin Uno. This makes the market only take action "wait and see" while looking for accurate information.

On May 21, 2019, the General Election Commission officially announced the results of the recapitulation of votes based on the real count stating that the Joko Widodo and Ma'ruf Amin pair won the general election. From t0 (event date) to t10 (ten days after the event date), there is no significant average abnormal return. That is because the market already believes in the Survey Institute quick count results that the Joko Widodo and Ma'ruf pair are the winners. In addition, the absence of a significant average abnormal return was also caused by riots due to dissatisfaction with supporters of Prabowo Subianto and Sandiaga Salahhudin Uno.

This research shows that, in investing investors must carefully analyze political issues to avoid risk. The results of data analysis prove there is a market reaction to the announcement of the election results of the President and Vice President of Indonesia in 2019. The results of this study are consistent with the results of research conducted by Imelda and Anggraeni (2014), Savita and Ramesh (2015), Kahn, et al. (2015), Koulakiotis, et al. (2016), Werth (2016), and Osuala, et al. (2018). But it is not consistent with the results of research conducted by Chandra (2015), Kabiru, et al. (2015), Sopyana and Yasa (2016), and Iyengar, et al. (2017) where political issues do not affect investor decisions.

Based on the results of the study, the theoretical and practical implications can be put forward. Theoretically the results of this study provide information that the political issues that existed during the announcement of the election results of the President and Vice President of Indonesia in 2019 caused the capital markets to react. These results are related to the Efficient Market Hypothesis theory, especially the event study testing method that tests the information content to see the market's reaction to an event whose information is published. The market reaction is measured using abnormal returns. If an event announcement contains information, it will give an abnormal return to the market, otherwise if an event does not contain information, it will not provide an abnormal return to the market. Practically the results of this study are used as information material for investors in the capital market, especially in addressing and reading situations related to political issues that can affect the investment world such as elections. From the results of this study, it is expected that investors can make the right investment decisions in the future.

\section{Conclusion}

Based on the results of data analysis, in the period of the announcement of the results of the general election based on the Survey Institute quick count, there was a significant positive average abnormal return on the second day after the event date. Based on this, it concludes that there is a market reaction to the announcement of the results of the 2019 Indonesian Presidential and Vice President elections based on the Survey Institute quick count. Whereas after the announcement of the general election results based on the real count of the General Election Commission, there was no significant abnormal return on average which concluded that the market did not react to the announcement of the election results of the President and Vice President of Indonesia in 2019 based on the General Election Commission real count.

Based on the limitations of the research and the conclusions that have been presented, then the advice that 
can be given to further researchers is, Researchers are expected to be able to reinforce the research area, such as examining per sector of shares that can be affected by the announcement of events, and pay attention to company size using profitability ratios such as Return On Equity, Price Earning Ratio, and so on. Furthermore, investors are expected to be able to find accurate information or be able to ascertain their truth and be able to predict situations that are influenced by political issues.

\section{References}

BBC. (2019), "Demo 22 Mei: Ambulans berlogo Gerindra 'mengangkut batu' saat protes di Bawaslu, Fadli Zon bantah", available on URL: https://www.bbc.com/indonesia/indonesia-48365914 accessed on June $14^{\text {rd }}, 2019$.

Binder, John J. (1998), “The Event Study Methodology Since 1969”. Review of Quantitative Finance and Accounting, 11 (1998): 111-137.

Brown, Keith C., and Frank K. Reilly. (2009), “Analysis of Investments And Management of Portfolio", Ninth Edition. South-Western Cengage Learning.

Chandra, Teddy. (2015), "Impacts Of Indonesia's 2014 Presidential Election Towards Stock Priceso Indonesia Stock Exchange", International Journal of Business and Management; Vol. 10, No. 7; 2015.

Fama, Eugene F. (1970), "Efficient Capital Markets: A Review Of Theory And Empirical Work", Journal of Finance, Vol. 25, Issue 2, Pp. 383-417.

Fama, Eugene F. (1991), "Efficient Capital Markets: II. The Journal Of Finance”, Vol. 46, No. 5, Pp. 1575-1617. Imelda, Hermanto Siregar and Lukytawati Anggraeni. (2014), "Abnormal Return And Trading Volume In The Indonesian Stock Market In Relation To The Presidential Elections In 2004, 2009, and 2014”, International Journal of Administrative Science \& Organization, Vol. 21 No. 2, Pp. 65-76.

Iyengar, Madhu., Nirmal Iyengar and Harmish Sampat. (2017), "Impact Of US Election Results On Indian Stock Market: An Event Study Approach”, International Journal of Applied Research 2017; 3(5): 09-13.

Kabiru, James Ndungu., Duncan Elly Ochieng and Hellen Wairimu Kinyua. (2015), "The Effect Of General Elections On Stock Returns At The Nairobi Securities Exchange", European Scientific Journal October 2015 edition, Vol. 11, No. 28, ISSN: 1857-7881.

Khan, Noman., Qaiser Aman and Muhammad Asad Khan. (2015), "Market Efficiency: National Elections And Stock Market", Journal of Managerial Sciences, Vol. 9, No. 2.

Komisi Pemilihan Umum. (2019), "Tahapan Program dan Jadwal Penyelenggaraan Pemilihan Umum Tahun 2019”, available on URL: https://infopemilu.kpu.go.id/pileg2019 accessed on June 12 ${ }^{\text {th }}, 2019$.

Kompas. (2019), "Polri: 9 Korban Meninggal Dunia Rusuh 21-22 Mei 2019 Kami Duga Perusuh", available on URL: https://nasional.kompas.com/read/2019/06/11/20190081/polri-9-korban-meninggal-dunia-rusuh-2122-mei-2019-kami-duga-perusuh accessed on June $14^{\text {th }}, 2019$.

Koulakiotis, Harry., and Nicholas. (2016), "Political Elections, Abnormal Returns And Stock Price Volatility: The Case Of Greece", Investment Management and Financial Innovations, Vol. 13, Issue 1, Pp. 161-169.

Osuala, A. E., U. A. Onoh and G. U. Nwansi. (2018), "Presidential Election Results And Stock Market Performance: Evidence From Nigeria", Applied Economics and Finance, Vol. 5, No. 2, Pp. 117-124.

Savita and A. Ramesh. (2015), "Return Volatility Around National Elections: Evidence from India", Procedia Social and Behavioral Sciences, Vol. 189, Pp. 163-168.

Sopyana, Ni Putu Linda. and Gerianta Wirawan Yasa. (2016), "Perbedaan Reaksi Pasar Modal Terhadap Peristiwa Pemilihan Presiden dan Wakil Presiden Republik Indonesia Tahun 2014”, Journal of Economic Studies Bulletin, Vol. 21, No. 2, Pp. 136-146.

Tribun Batam. (2019), "Penyebab Pengumuman Pilpres 2019 Dimajukan, Ketua KPU Beber Alasannya", available on URL: https://batam.tribunnews.com/2019/05/21/penyebab-pengumuman-pilpres-2019-dimajukan-ketuakpu-beber-alasannya accessed on June $13^{\text {th }}, 2019$.

Werth, Luca Camilla. (2016), "Brazil's 2014 Presidential Elections: The Interconnection Between Election News And Stock Market Behaviour", Dissertacao apresentada a Escola de Economia de Empresas de Sao Paulo da Fundacao Getulio Vargas.

Wiagustini, Ni luh Putu. (2014), “Dasar-Dasar Manajemen Keuangan”, Udayana University Press.

Wiksuana, I Gusti Bagus. (2017), "Manajemen Portfolio Saham Based on Empirical Research”, ESBE book.

www.finance.yahoo.com

www.idx.co.id 